\title{
Erratum to: Light alkane aromatization over modified Zn-ZSM-5 catalysts: characterization of the catalysts by hydrogen/deuterium isotope exchange
}

\author{
Krisztina Frey • Louis M. Lubango • \\ Mike S. Scurrell • László Guczi
}

Published online: 4 November 2011

(C) Akadémiai Kiadó, Budapest, Hungary 2011

\section{Erratum to: React Kinet Mech Cat DOI 10.1007/s11144-011-0382-4}

Due to an unfortunate mistake in the production process, the column heading of Table 2 is displayed incorrect in the above mentioned publication. The correct representation of Table 2 is published below and should be treated as definitive by the reader.

The online version of the original article can be found under doi:10.1007/s11144-011-0382-4.

K. Frey $(\bowtie) \cdot$ L. Guczi

Department of Surface Chemistry and Catalysis, Institute of Isotopes, P.O. Box 77, Budapest 1525, Hungary

e-mail: frey@mail.kfki.hu 
Table 2 Propane conversion over Me-Zn/ZSM-5-based catalysts ${ }^{\mathrm{a}}$

\begin{tabular}{llllll}
\hline $\begin{array}{l}\text { Nature of Me } \\
\text { Conversion (\%) }\end{array}$ & - & $\mathrm{Cr}$ & $\mathrm{Co}$ & $\mathrm{Mn}$ & $\mathrm{Fe}$ \\
\hline Exit stream & 24 & 35 & 42 & 35 & 46 \\
$\begin{array}{l}\text { Composition (\%C) } \\
\text { Methane }\end{array}$ & 1.8 & 3.7 & 3.5 & 2.6 & 3.1 \\
$\mathrm{C}_{2}$ & 1.6 & 2.4 & 4.6 & 2.3 & 2.0 \\
$\mathrm{C}_{4}+\mathrm{C}_{5}$ & 0.7 & 0.2 & - & - & 0.1 \\
Benzene & 6.3 & 10.0 & 14.1 & 11.8 & 15.1 \\
Toluene & 6.8 & 10.8 & 14.9 & 12.6 & 17.8 \\
Xylenes & 3.4 & 5.0 & 6.0 & 5.9 & 8.6 \\
$\mathrm{C}_{9+}$ & 0.1 & - & - & - & - \\
BTX selectivity (\%C) & 69 & 81 & 74 & 87 & 91 \\
\hline
\end{tabular}

${ }^{\mathrm{a}} 0.5 \mathrm{mass} \% \mathrm{Zn}$ and 1.0 mass\% $\mathrm{Me}$ 